
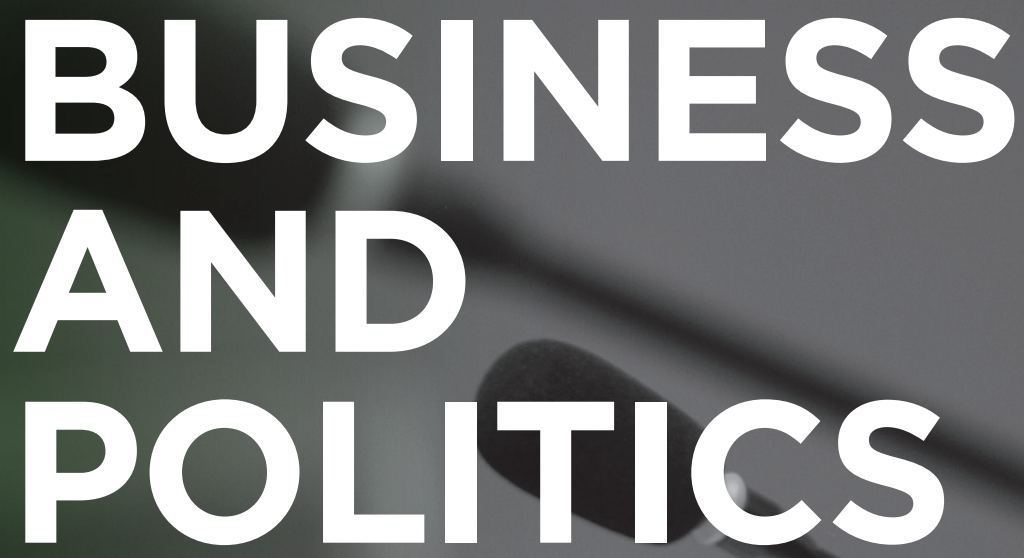

\title{
EDITOR-IN-CHIEF
}

Vinod K. Aggarwal
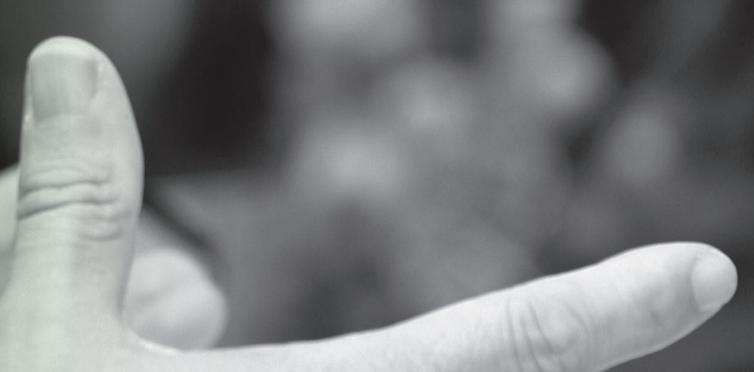


\section{BUSINESS AND POLITICS}

\section{EDITOR-IN-CHIEF}

Vinod K. Aggarwal, University of California, USA

\section{ASSOCIATE EDITORS}

Maxwell Cameron, University of British Columbia, Canada

Cédric Dupont, The Graduate Institute, Switzerland

Thomas Gilligan, University of Texas, USA

Witold Henisz, University of Pennsylvania, USA

Keith Krehbiel, Stanford University, USA

John Ravenhill, Australian National University, Australia

\section{MANAGING EDITOR}

Philip Rocco, University of California, USA

\section{ASSISTANT MANAGING EDITOR}

Christopher Adam Hussey, University of California, USA

\section{DE GRUYTER}


Business and Politics (BAP) solicits articles within the broad area of the interaction between firms and political actors. Two specific areas are of particular interest to the journal. The first concerns the use of non-market corporate strategy. These efforts include internal organizational design decisions as well as external strategies. Internal organizational design refers to management structure, sourcing decisions, and transnational organization with respect to the firm's non-market environment. External strategies include legal tactics, testimony, lobbying and other means to influence policymakers at all levels of government and international institutions as an adjunct to market strategies of the firm. A second area of interest involves efforts by policymakers to influence firm behavior through regulatory, legal, financial, and other government instruments.

ABSTRACTED/INDEXED IN ABI/Inform, CSA/Proquest: Environmental Science and Pollution Management, PAIS International, Risk Abstracts, Social Services Abstracts, Sociological Abstracts, Worldwide Political Science Abstracts, Dietrich's Index Philosophicus, EconLit, Elsevier: Scopus, International Bibliography of the Social Sciences, OCLC: WorldCat, Research Papers in Economics (RePEc).

ISSN 1369-5258 · e-ISSN 1469-3569

All information regarding notes for contributors, subscriptions, Open Access, back volumes and orders is available online at http://www.degruyter.com/bap.

RESPONSIBLE EDITOR Vinod K. Aggarwal, Department of Political Science and Haas School of Business, 802 Barrows Hall, 1970b, University of California, Berkeley, CA, 94720-1970, Email: bap@socrates.berkeley.edu

JOURNAL MANAGER Holger Kleessen, De Gruyter, Genthiner Straße 13, 10785 Berlin, Germany. Tel.: +49 (0)30 260 05-376, Fax: +49 (0)30 260 05-250,

Email: holger.kleessen@degruyter.com

RESPONSIBLE FOR ADVERTISEMENTS Panagiota Herbrand, De Gruyter, Rosenheimer Straße 143, 81671 München, Germany, Tel.: +49 (0)89 76902 - 394, Fax: +49 (0)89 76902 - 350,

Email: panagiota.herbrand@degruyter.com

TYPESETTING Compuscript Ltd, Shannon, Ireland

PRINTING Franz X. Stückle Druck und Verlag e.K., Ettenheim

(C) 2013 Walter de Gruyter GmbH, Berlin/Boston

Printed in Germany

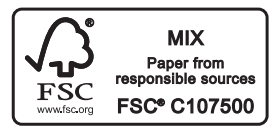




\section{Contents}

Jean-Philippe Bonardi and Santiago Urbiztondo

Asset freezing, corporate political resources and the Tullock paradox -275

Nimah Mazaheri

The Saudi monarchy and economic familism in an era of business environment reforms -295

Tricia D. Olsen and Aseema Sinha

Linkage politics and the persistence of national policy autonomy in emerging powers: patents, profits, and patients in the context of TRIPS compliance - 323

Hugh Compston

The network of global corporate control: implications for public policy - 357

Bessma Momani

Management consultants and the United States' public sector - 381

Daniel E. Chand and William D. Schreckhise

Keeping score on congress: explaining variations in interest group ratings of US senators - 401 